\title{
Inhibition of histamine-stimulated gastric secretion by acid in the duodenum in man
}

\author{
D. JOHNSTON AND H. L. DUTHIE \\ From the University Department of Surgery, Royal Infirmary, Sheffield
}

EDITORIAL SYNOPSIS These studies on the inhibition of gastric secretion due to acid in the duodenum are compatible with the hypothesis that a hormone is involved in that inhibition. This would explain the inhibition noted in cross-transfusion tests but not in control cross-transfusions. Secretin, pancreozymin, and cholecystokinin do not appear to be concerned in this phenomenon.

Histamine-stimulated gastric secretion in man is inhibited when the intraduodenal $p \mathrm{H}$ is reduced to 2.5 or less (Johnston and Duthie, 1964). The characteristics of the inhibition are these (Fig. 1); the onset is rapid, within two minutes; the degree depends on the potency of the stimulant and inhibitor, but is about $57 \%$ in normal subjects when the dose of histamine is $0.2 \mu \mathrm{g} . / \mathrm{kg}$. $/ \mathrm{min}$. and the $p \mathrm{H}$ in the duodenum about $1 \cdot 4$. Inhibition usually ceases promptly when acid perfusion of the duodenum is stopped. The concentration of acid secreted is not affected, the inhibition affecting only the volume and output of acid.

The mechanism of this inhibition is not known. The rapid onset and decay which we have noted suggest that nervous reflexes play a part. The evidence from experiments on dogs has been conflicting, Code and Watkinson (1955), Pappas

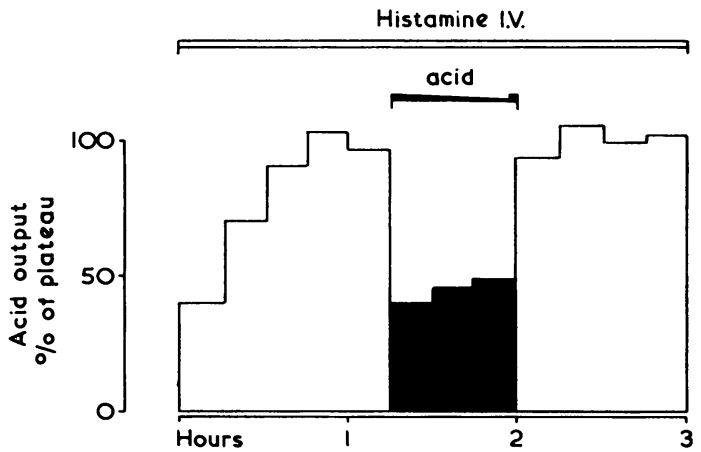

FIG. 1. A diagram to illustrate the main features of the inhibitory test: acid in the duodenum inhibits histaminestimulated gastric secretion promptly and by about $50 \%$. and Code (1963), and Sircus (1958) favouring the 'nervous' theory, while Andersson (1960a and b) has suggested a humoral basis because he was able to demonstrate some inhibition of secretion in denervated pouches. In man, secretin given intravenously has been shown to inhibit gastric secretion stimulated by broth (Kamionkowski, Grossman, and Fleschler, 1964) but there is no evidence about the mechanism of duodenal inhibition of histaminestimulated gastric secretion. This paper presents the results of an investigation in this field which lead us to believe that a hormonal substance is partly responsible for the inhibition.

\section{MATERIAL AND METHODS}

We approached the problem in three different ways: 1 cross-transfusion from subjects with acid in the duodenum (four tests); 2 men after surgical vagotomy having acid put into the duodenum (six tests); 3 effect of the gastro-intestinal extracts ${ }^{1}$, secretin (seven tests), pancreozymin (10 tests), and cholecystokinin (five tests).

The method used to assess the inhibitory effect of duodenal acidification on gastric secretion ('inhibitory test') has been described previously (Johnston and Duthie, 1964) and will now be outlined.

THE INHIBITORY TEST Gastric secretion was stimulated by a continuous infusion of histamine acid phosphate, the dose of from 0.05 to $0.1 \mu \mathrm{g} . / \mathrm{kg}$. $/ \mathrm{min}$. giving secretory levels $50 \%$ or less of the maximum. When a steady rate of secretion had been established $\mathrm{N} / 10$ hydrochloric acid was perfused through the proximal duodenum, by a method designed to minimize reflux into the stomach; the extent of any such reflux was estimated precisely by

${ }^{1}$ The secretin and pancreozymin were obtained from Boots Pure Drug Co. and cholecystokinin (Cecekin) from Vitrum Co., Stockholm. 


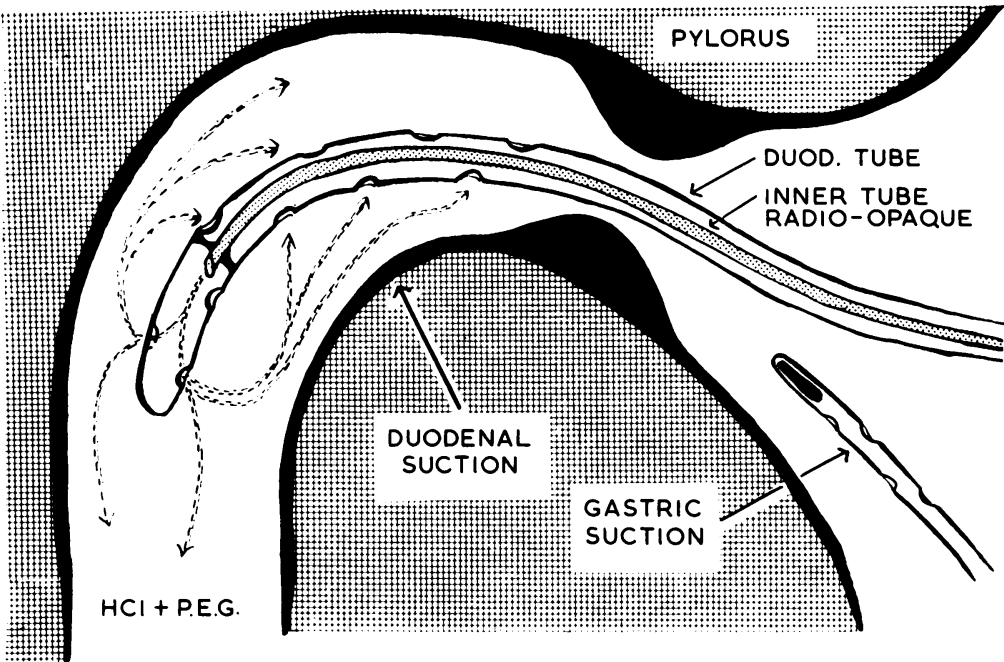

FIG. 2. The perfusion system.

the use of the inert marker, polyethylene glycol (P.E.G.). If there was reflux of more than $5 \mathrm{ml}$. of acid fluid, the test was discarded. The position of the tubes was checked radiographically at least once in the course of the test.

Continuous suction was applied to the tubes in the stomach and the duodenum, separate specimens being collected for each 15-minute period. In many tests, however, in order to define more exactly the timerelationships of the inhibition, separate samples were collected for each five-minute period, before, during, and immediately after either the infusion of acid into the duodenum or the intravenous infusion of extracts of duodenal mucosa.

Estimations on gastric juice Measurements were made of volume, $p \mathrm{H}$, free and total acid, and the electrolytes sodium, potassium, and chloride, as described in the previous paper. In addition, in some tests, pepsin concentration was estimated by the method of Hunt (1948). Inhibition of gastric secretion was expressed as a percentage of the plateau level.

Estimations on duodenal aspirate The estimations were of volume, $p \mathrm{H}$, free and total acid, and concentration of polyethylene glycol.

CROSS-TRANSFUSION TESTS In view of the well-known risks of blood transfusion (Mollison, 1961), the first three experiments were conducted among members of the Surgery Department, and the hazards were fully discussed with all subsequent volunteers. The subjects were paired according to their ABO and Rhesus blood group. The donor underwent the standard inhibitory test. When duodenal acidification had led to inhibition of gastric secretion, 1 pint of blood was taken in 10 to 15 minutes from an arm vein into a polyethylene bag containing 2,250 units of heparin in $30 \mathrm{ml}$. normal saline as the anticoagulant. The recipient, meantime, had a gastric tube in position and his gastric secretion was being stimulated by a histamine infusion. A plateau of secretion having been established, the blood from the donor was infused rapidly intravenously in 10 to 15 minutes, after which the test was continued for about an hour. In all tests, care was taken to synchronize proceedings, so that blood removed could be infused immediately, in order to minimize any alteration in possible humoral content. Six such tests were performed, of which two were discarded, one because of excessive reflux of alkaline fluid into the antrum in the donor's test, the other because acid from the donor's stomach passed into the duodenum during the control period, creating an acid $p \mathrm{H}$ and thus invalidating the control.

Control studies First of all, to exclude the possibility that the infusion of any type of blood might inhibit gastric secretion, the effect on histamine-stimulated gastric secretion of intravenous infusion of 1 pint of 'bank' blood was observed in three patients awaiting operation for duodenal ulcer. It was fully realized, of course, that this 'control' was not complete, since the blood was not fresh, was infused in one hour, and was anticoagulated not with heparin but with acid citrate dextrose.

The next three control studies were identical to the cross-transfusion tests, except that no acid was introduced into the donor's duodenum: in one of the three, saline was infused into the donor's duodenum and in the other two no fluid was introduced into the duodenum. There was no difference between test and control in the volume of blood transfused, rate of transfusion, or dose of heparin.

Finally, because heparin has been shown to inhibit histamine-stimulated gastric secretion in man (Thompson and Lerner, 1963), six tests were performed to find out whether the small amount of heparin used in the above tests had contributed to the inhibition. Gastric secretion was stimulated by histamine infused intravenously in a dose of 0.05 to $0.1 \mu \mathrm{g}$. $/ \mathrm{kg}$. body weight $/$ minute, and the effect of administering 2,250 units of heparin in $500 \mathrm{ml}$. $0.9 \%$ saline or plasma in 10 to 15 minutes was observed.

MEN AFTER SURGICAL VAGOTOMY A subdiaphragmatic vagotomy without any drainage procedure had been 
performed in the treatment of chronic duodenal ulceration 15 years previously. The absence of a stoma in the stomach made these tests possible: attempts to perfuse the duodenum in patients with a pyloroplasty or a gastrojejunostomy failed because of massive reflux into the stomach. The results of six inhibitory tests are reported. At the time of testing, the subjects were in excellent health except one who had epigastric pain and later proved to have a positive Hollander test (no. 6, Table III). An insulin test of gastric secretion had been performed in five patients soon after their operation and in the present study this was repeated in four out of the six, in addition to the performance of the inhibitory test. Sixteen units of soluble insulin were given intravenously after the control hour and secretion followed for a further two hours. The response was designated 'positive' or 'negative' according to the criteria of Hollander (1948). A further 12 inhibitory tests were attempted but discarded: four because the subjects were achlorhydric to the infusion of histamine, four because the duodenal tube could not be manoeuvred out of the big, dilated stomach, two because no satisfactory plateau of gastric secretion was obtained during histamine infusion, and two on account of excessive reflux of duodenal content into the stomach.

GASTROINTESTINAL HORMONAL PREPARATIONS In this phase of the study, one of the three extracts of duodenal mucosa-secretin (Boots), pancreozymin (Boots), or cholecystokinin (Cecekin, Vitrum)-was injected slowly intravenously and the effect on gastric acid secretion observed. These are impure extracts of intestinal mucosa and are designated 'secretin', 'pancreozymin', and 'cholecystokinin' for ease of discussion. The 'pancreozymin' contains much cholecystokinin and the 'cholecystokinin' much pancreozmyin. The 'secretin' too is far from pure. In all tests, small doses of histamine acid phosphate, from 0.05 to $0.1 \mu \mathrm{g} . / \mathrm{kg}$. $/ \mathrm{min}$., were given intravenously and resulted in secretory levels about $50 \%$ or less of the maximum.

An intraduodenal tube was omitted in some early tests, but the high incidence of reflux of bile and pancreatic juice from the duodenum into the stomach after the injection of the hormones led to a modification in technique, whereby a fine radio-opaque polyethylene tube was placed in the duodenum to drain the secretions elicited.

Secretin Secretin (Boots) was given intravenously in doses of from 70 to 100 units, over six to 10 minutes, after a steady level of gastric acid secretion had been reached in response to intravenous histamine. Seven tests were valid. Three of the subjects were normal and four had duodenal ulcer. Two other tests were discarded because of the rapid appearance of massive reflux of alkaline duodenal content into the stomach soon after the injection of secretin.

Pancreozymin (Boots) This was administered as above, except that it had to be given more slowly in a dose of 90 to 145 units over 12 to 40 minutes, because rapid administration was always found to elicit epigastric pain. Ten tests were performed.

Cholecystokinin Cecekin was given intravenously in a dose of 75 units over 12 to 20 minutes. Five tests were carried out. Fairly slow injection was again found to be necessary to avoid nausea and epigastric discomfort.

\section{RESULTS}

CROSS-TRANSFUSION EXPERIMENTS In all tests, the transfused blood inhibited the recipient's gastric secretion (Table 1, Fig. 3). The mean inhibition was $51.5 \%$. The inhibition affected the volume of gastric juice and the acid output, but no significant change in concentration of acid, of pepsin, or of electrolytes was seen. Secretion of free acid was completely inhibited in subject no. 2 (Table I): for this reason, despite the large decrease in total acid concentration, it was not justifiable to include this $85 \%$ change when the mean change in acid concentration was calculated. Inhibition was of rapid onset, within two minutes in three of the four tests. On average, gastric secretion was inhibited during the infusion of blood and for five to 15 minutes after it. In test no. 1 inhibition appeared to pass off while blood was still being infused.

Control studies Transfusion of 'bank' blood was accompanied by a slight rise (about $15 \%$ ) in gastric acid secretion. No inhibition was seen when fresh blood was cross-transfused in any of the three experiments. Heparin, 2,250 units, in $500 \mathrm{ml}$. of saline or plasma did not inhibit gastric secretion (Table II, Fig. 4). The $38 \%$ inhibition in test 9 is not significant, as is readily apparent from a perusal

TABLE I

INHIBITORY EFFECT ON HISTAMINE-STIMULATED GASTRIC SECRETION OF BLOOD IN CROSS-TRANSFUSION TESTS ${ }^{1}$

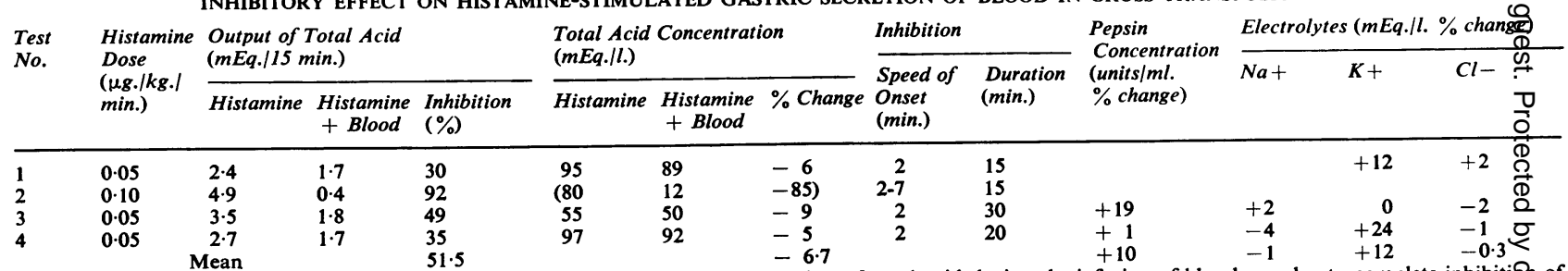

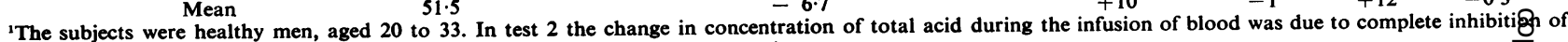
secretion of free acid and as such has been excluded from the mean percentage change. 

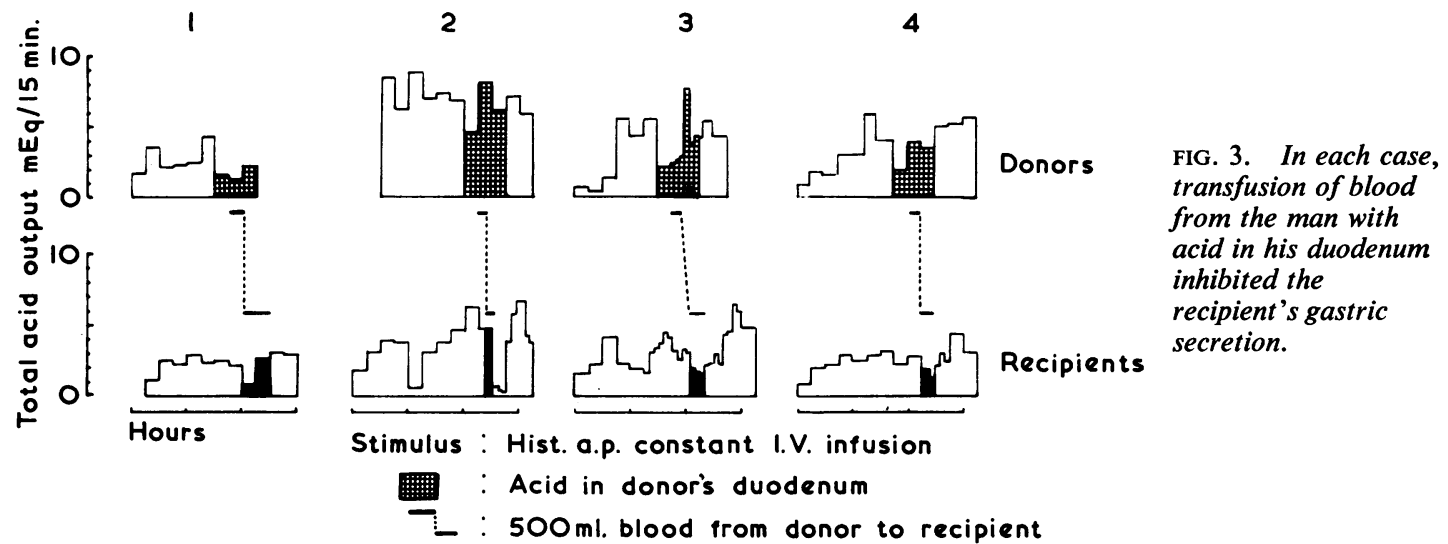

TABLE II

EFFECT OF TRANSFUSION OF $500 \mathrm{ml}$. BLOOD, PLASMA, OR SALINE IN CONTROLS FOR CROSS-TRANSFUSION TESTS

\begin{tabular}{|c|c|c|c|c|c|c|c|c|c|c|c|}
\hline \multirow{3}{*}{$\begin{array}{l}\text { Test } \\
\text { No. }\end{array}$} & \multirow[t]{3}{*}{ Diagnosis } & \multirow[t]{3}{*}{$\begin{array}{l}\text { Fluid Transfused } \\
(500 \mathrm{ml} .)\end{array}$} & \multirow[t]{3}{*}{ Anticoagulant } & \multirow{3}{*}{$\begin{array}{l}\text { Duration } \\
\text { of Trans- } \\
\text { fusion } \\
\text { (min.) }\end{array}$} & \multirow{3}{*}{$\begin{array}{l}\text { Dose of } \\
\text { Histamine } \\
\text { ( } \mu \mathrm{g} . / \mathrm{kg} . / \\
\text { min.) }\end{array}$} & \multirow{2}{*}{\multicolumn{3}{|c|}{$\begin{array}{l}\text { Output of Total Acid } \\
\text { (mEq./15 min.) }\end{array}$}} & \multicolumn{3}{|c|}{ Acid Concentration ( $m E q . / l)}$. \\
\hline & & & & & & & & & \multirow{2}{*}{ Histamine } & \multirow{2}{*}{$\begin{array}{l}\text { Histamine } \\
+ \text { Trans- } \\
\text { fusion } \\
\text { Fluid }\end{array}$} & \multirow{2}{*}{$\%$ Change } \\
\hline & & & & & & Histamine & $\begin{array}{l}\text { Histamine } \\
+ \text { Trans- } \\
\text { fusion } \\
\text { Fluid }\end{array}$ & $\%$ Change & & & \\
\hline 1 & Duodenal ulcer & Bank blood & Acid citrate dextrose & 60 & 0.05 & 4.9 & $5 \cdot 8$ & +19 & 109 & 112 & +2 \\
\hline 2 & Duodenal ulcer & Bank blood & Acid citrate dextrose & 60 & 0.05 & 3.8 & $4 \cdot 5$ & +20 & 106 & 109 & $+\overline{3}$ \\
\hline \multirow[t]{2}{*}{3} & Duodenal ulcer & Bank blood & Acid citrate dextrose & 60 & 0.05 & $5 \cdot 8$ & $6 \cdot 2$ & +6 & 102 & 120 & +18 \\
\hline & & Mean & & & & $4 \cdot 8$ & $5 \cdot 5$ & +15 & 106 & 113 & $+7 \cdot 5$ \\
\hline 4 & Normal & Fresh blood: nil in & Heparin & 15 & 0.05 & $4 \cdot 9$ & $5 \cdot 4$ & +10 & 108 & 116 & +7 \\
\hline 5 & Normal & duodenum of donor & $2,250 \mathrm{u}$. & 15 & 0.075 & $5 \cdot 2$ & $5 \cdot 7$ & +9 & 80 & 84 & +5 \\
\hline 6 & Normal & Fresh blood: saline & Heparin & 15 & 0.05 & $5 \cdot 3$ & $5 \cdot 8$ & +11 & 146 & 129 & -12 \\
\hline 7 & Normal & $0.9 \%$ saline & Heparin $2,250 \mathrm{u}$. & 15 & 0.05 & $2 \cdot 3$ & 3.4 & +48 & 92 & 98 & +7 \\
\hline 8 & Normal & $0.9 \%$ saline & Heparin 2,250 u. & 15 & $0 \cdot 10$ & 2.9 & 3.0 & +4 & 94 & 66 & -30 \\
\hline 9 & Normal & $0.9 \%$ saline & Heparin $2,250 \mathrm{u}$. & 15 & 0.05 & $0 \cdot 6$ & 0.4 & -38 & 29 & 30 & +4 \\
\hline 10 & Normal & Plasma & Heparin $2,250 \mathrm{u}$. & 15 & 0.05 & $2 \cdot 1$ & $3 \cdot 0$ & +43 & 63 & 78 & +24 \\
\hline 11 & Duodenal ulcer & Plasma & Heparin $2,250 \mathrm{u}$. & 15 & 0.05 & $2 \cdot 8$ & $2 \cdot 7$ & -4 & 99 & 76 & -23 \\
\hline \multirow[t]{2}{*}{12} & Normal & Plasma & Heparin $2,250 \mathrm{u}$. & 15 & $0 \cdot 10$ & 1.5 & $1 \cdot 8$ & +19 & 69 & 73 & +6 \\
\hline & & Mean & & & & & & +12 & & & -2.0 \\
\hline
\end{tabular}

TABLE III

INHIBITORY EFFECT ON GASTRIC SECRETION OF ACID IN THE DUODENUM IN MEN WITH SURGICAL VAGOTOMY ${ }^{1}$

\begin{tabular}{|c|c|c|c|c|c|c|c|c|}
\hline \multirow{2}{*}{$\begin{array}{l}\text { Subject } \\
\text { No. }\end{array}$} & \multirow{2}{*}{$\begin{array}{l}\text { Age } \\
(y r .)\end{array}$} & \multirow{2}{*}{$\begin{array}{l}\text { Dose of } \\
\text { Histamine } \\
(\mu \mathrm{g} . / \mathrm{kg} . / \mathrm{min} .)\end{array}$} & \multicolumn{3}{|c|}{ Output of Total Acid (mEq./15 min.) } & \multirow{2}{*}{$\begin{array}{l}\text { Duration o. } \\
\text { Inhibition } \\
\text { (hours) }\end{array}$} & \multicolumn{2}{|c|}{ Insulin Test } \\
\hline & & & Histamine & Histamine + Acid & Inhibition (\%) & & 1950 & 1964 \\
\hline $\begin{array}{l}1 \\
2 \\
3 \\
4 \\
5 \\
6\end{array}$ & $\begin{array}{l}53 \\
53 \\
60 \\
37 \\
39 \\
35\end{array}$ & $\begin{array}{l}0 \cdot 2 \\
0 \cdot 2 \\
0 \cdot 2 \\
0 \cdot 2 \\
0 \cdot 2 \\
0 \cdot 2\end{array}$ & $\begin{array}{l}1 \cdot 75 \\
3 \cdot 20 \\
0.77 \\
2.90 \\
1 \cdot 17 \\
3.81\end{array}$ & $\begin{array}{l}1.45 \\
2.83 \\
0.57 \\
1.83 \\
0.82 \\
2.74\end{array}$ & $\begin{array}{l}17 \cdot 1 \\
11 \cdot 6 \\
25 \cdot 5 \\
36 \cdot 7 \\
30 \cdot 0 \\
28 \cdot 0\end{array}$ & $\begin{array}{l}\frac{8}{4} \\
\frac{8}{4} \\
\frac{1}{4} \\
1 \\
\frac{8}{4} \\
1\end{array}$ & $\begin{array}{l}\text { - ve } \\
\text { - ve } \\
\text { - ve } \\
+ \text { ve } \\
\text { +ve }\end{array}$ & $\begin{array}{l}+v e \\
+v e \\
+v e\end{array}$ \\
\hline
\end{tabular}

${ }^{1}$ All were in good health except number 6, who had epigastric pain. Duodenal $p \mathrm{H}$ was less than 2.5 during acid perfusion in all six tests. 
of the graph in Fig. 4, which shows that the levels of acid secretion were low, with large deviations from the mean during the control period.

Side effects There were no severe or dangerous side effects. Two recipients developed pyrexial 'influenzal' illnesses one to two days after the test, and lasting about three days.

SURGICAL VAGOTOMY A decrease in gastric secretion during the perfusion of the duodenum with acid was noted in all six tests. Its degree varied from 12 to $37 \%$ (Table III, Fig. 5). It will be seen that the vagotomy was complete, according to the criteria of Hollander (1948), in tests 1, 2, and 3, and incomplete in nos. 4,5 , and 6 . A further weakness of this phase of the study is that we had to rely on the results of the post-operative insulin tests in subjects 2 and 3 who were unwilling to undergo two tests by us. The mean inhibition was $32 \%$ in the subjects with incomplete vagotomy and only $18 \%$ in those who seemed to have had complete vagal section.

SECRETIN The acid output diminished in three tests and increased in four during the intravenous infusion of secretin (Table IV, Fig. 6). There was a mean increase of $3.6 \%$ and in the ensuing 15 -minute period the mean acid output was $14.5 \%$ greater than in the control period. These changes are not significant $(P>0.9)$. The concentration of acid secreted was not affected except in no. 7 where the decrease was due to reflux of alkaline duodenal juice. In one test only (no. 4) was the decrease in secretion large $(25 \%)$. Its duration was 20 minutes, 10 minutes during the secretin infusion plus the ensuing 10 minutes. The pepsin concentration was estimated in three tests: it increased in one, decreased in one, and in one was unchanged: there was a mean increase of $8 \%$.

TABLE IV

EFFECTS OF BOOTS'S SECRETIN ON HISTAMINE-STIMULATED GASTRIC SECRETION

\begin{tabular}{|c|c|c|c|c|c|c|c|c|c|c|c|c|}
\hline \multirow{3}{*}{$\begin{array}{l}\text { Subject } \\
\text { No. }\end{array}$} & \multirow{3}{*}{$\begin{array}{l}\text { Age } \\
(y r .)\end{array}$} & \multirow[t]{3}{*}{ Diagnosis } & \multirow{3}{*}{$\begin{array}{l}\text { Dose of } \\
\text { Histamine } \\
(\mu \mathrm{g} . / \mathrm{kg} . / \mathrm{min} .)\end{array}$} & \multirow{3}{*}{$\begin{array}{l}\text { Dose of } \\
\text { Secretin } \\
\text { (units) }\end{array}$} & \multirow{3}{*}{$\begin{array}{l}\text { Time to } \\
\text { Inject } \\
\text { Secretin } \\
\text { (min.) }\end{array}$} & \multicolumn{4}{|c|}{ Output of Total Acid (mEq./15 min.) } & \multirow{2}{*}{\multicolumn{2}{|c|}{$\begin{array}{l}\text { Concentration Total Acid } \\
(m E q . / l .)\end{array}$}} & \multirow{2}{*}{$\begin{array}{l}\text { Percentag } \\
\text { Change } \overline{1} \\
\text { Pepsin } \\
\text { Concent }\end{array}$} \\
\hline & & & & & & Plateau & Intravenous & Percentage & Percentage & & & \\
\hline & & & & & & $\begin{array}{l}\text { before } \\
\text { Secretin }\end{array}$ & Secretin & Change & $\begin{array}{l}\text { Change } \\
\text { of Plateau } \\
15 \text { Minutes } \\
\text { after } \\
\text { Secretin }\end{array}$ & $\begin{array}{l}\text { Before } \\
\text { Secretin }\end{array}$ & Secretin & $\begin{array}{l}\text { Concent } \\
\text { tion }\end{array}$ \\
\hline \multirow{8}{*}{$\begin{array}{l}1 \\
2 \\
3 \\
4 \\
5 \\
6 \\
7\end{array}$} & 50 & Normal & 0.08 & 100 & 10 & 4.57 & 5.07 & +10.9 & +14 & 109 & 114 & \\
\hline & 45 & Normal & 0.06 & 95 & 8 & $2 \cdot 90$ & $2 \cdot 57$ & -11.4 & RX & 72 & 72 & \\
\hline & 35 & Normal & $0 \cdot 10$ & 100 & 10 & $3 \cdot 13$ & 3.97 & +26.9 & $\mathbf{R X}$ & 86 & 79 & \\
\hline & 51 & Duodenal ulcer & 0.05 & 95 & 10 & $7 \cdot 60$ & $5 \cdot 70$ & $-25 \cdot 0$ & -24 & 126 & 130 & +28.6 \\
\hline & 59 & Duodenal ulcer & $0 \cdot 10$ & 70 & 6 & $5 \cdot 64$ & $6 \cdot 87$ & $+21 \cdot 8$ & -9 & 122 & 104 & \\
\hline & 54 & Duodenal ulcer & 0.05 & 100 & 6 & $3 \cdot 11$ & $3 \cdot 39$ & +9.0 & +77 & 100 & 102 & 0 \\
\hline & 40 & Duodenal ulcer & $0 \cdot 10$ & 100 & 9 & $4 \cdot 63$ & $4 \cdot 32$ & -6.7 & $\mathbf{R X}$ & 99 & 76 & $-4 \cdot 7$ \\
\hline & & Mean & & & & & & +3.6 & $+14 \cdot 5$ & 102 & $97 \cdot 6$ & $+8 \cdot 0$ \\
\hline
\end{tabular}

$\mathbf{R X}=$ excessive reflux from the duodenum

TABLE V

EFFECT OF BOOTS'S PANCREOZYMIN ON HISTAMINE-STIMULATED GASTRIC SECRETION

\begin{tabular}{|c|c|c|c|c|c|c|c|c|c|c|c|c|c|c|}
\hline \multirow[t]{2}{*}{$\begin{array}{l}\text { Subject } \\
\text { No. }\end{array}$} & \multirow[t]{2}{*}{$\begin{array}{l}\text { Age } \\
(y r .)\end{array}$} & \multirow[t]{2}{*}{ Diagnosis } & \multirow{2}{*}{$\begin{array}{l}\text { Dose of } \\
\text { Histamine } \\
(\mu g . / k g . / \\
\text { min. })\end{array}$} & \multirow{2}{*}{$\begin{array}{l}\text { Dose of } \\
\text { Pancreo- } \\
\text { zymin } \\
\text { (units) }\end{array}$} & \multirow{2}{*}{$\begin{array}{l}\text { Time to } \\
\text { Inject } \\
\text { Pancreo- } \\
\text { zymin } \\
\text { (min.) }\end{array}$} & \multirow{2}{*}{$\begin{array}{l}\text { Plateau } \\
\text { Before } \\
\text { Pancreo- } \\
\text { zymin }\end{array}$} & \multicolumn{3}{|c|}{$\begin{array}{l}\text { Output of Total Acid } \\
\text { (mEq./15 min.) }\end{array}$} & \multicolumn{2}{|c|}{$\begin{array}{l}\text { Concentration of Total } \\
\text { Acid }(m E q . \mid l .)\end{array}$} & \multicolumn{3}{|c|}{$\begin{array}{l}\text { Percentage Change in } \\
\text { Electrolyte Concentration }\end{array}$} \\
\hline & & & & & & & $\begin{array}{l}\text { Pancreo- } \\
\text { zymin }\end{array}$ & $\begin{array}{l}\% \\
\text { Change }\end{array}$ & $\begin{array}{l}\% \\
\text { Change } \\
\text { of } \\
\text { Plateau } \\
15 \\
\text { Minutes } \\
\text { after } \\
\text { Pancreo- } \\
\text { zymin }\end{array}$ & $\begin{array}{l}\text { Before } \\
\text { Pancreo- } \\
\text { zymin }\end{array}$ & $\begin{array}{l}\text { Pancreo- } \\
\text { zymin }\end{array}$ & $\mathrm{Na}+$ & $\boldsymbol{K}+$ & $\mathrm{Cl}-$ \\
\hline
\end{tabular}

\begin{tabular}{|c|c|c|c|c|c|c|c|c|c|c|c|c|c|c|c|}
\hline $\begin{array}{r}1 \\
2 \\
3 \\
4 \\
5 \\
6 \\
7 \\
8 \\
9 \\
10\end{array}$ & $\begin{array}{l}30 \\
56 \\
40 \\
25 \\
49 \\
47 \\
20 \\
27 \\
20 \\
65\end{array}$ & $\begin{array}{l}\text { Normal } \\
\text { Normal } \\
\text { Normal } \\
\text { Normal } \\
\text { Normal } \\
\text { Gastric ulcer } \\
\text { Normal } \\
\text { Normal } \\
\text { Normal } \\
\text { Duodenal ulcer }\end{array}$ & $\begin{array}{l}0 \cdot 1 \\
0 \cdot 4 \\
0 \cdot 1 \\
0 \cdot 1 \\
0 \cdot 1 \\
0 \cdot 1 \\
0.075 \\
0 \cdot 075 \\
0.075 \\
0.075\end{array}$ & $\begin{array}{r}100 \\
90 \\
90 \\
145 \\
145 \\
90 \\
90 \\
90 \\
90 \\
90\end{array}$ & $\begin{array}{l}12 \\
15 \\
15 \\
17 \\
30 \\
30 \\
15 \\
15 \\
20 \\
15\end{array}$ & $\begin{array}{r}4 \cdot 99 \\
4 \cdot 32 \\
3 \cdot 11 \\
5 \cdot 33 \\
5 \cdot 68 \\
3 \cdot 50 \\
4 \cdot 10 \\
4 \cdot 64 \\
3.90 \\
12 \cdot 00 \\
\text { Mean }\end{array}$ & $\begin{array}{l}4 \cdot 01 \\
3 \cdot 81 \\
3 \cdot 06 \\
3 \cdot 67 \\
5 \cdot 98 \\
5 \cdot 04 \\
7 \cdot 48 \\
5 \cdot 44 \\
4 \cdot 23 \\
8 \cdot 45\end{array}$ & $\begin{array}{r}-19.7 \\
-11.8 \\
-1.6 \\
-23.6 \\
+5.3 \\
+44.0 \\
+82.4 \\
+17.2 \\
+8.4 \\
-29.6 \\
+6.10\end{array}$ & $\begin{array}{l}+30 \\
\text { Reflux } \\
-10 \\
+27 \\
\text { Reflux } \\
\text { Reflux } \\
+81 \\
+2 \\
-1 \\
-11 \\
+17\end{array}$ & $\begin{array}{r}125 \\
109 \\
88 \\
150 \\
114 \\
86 \\
95 \\
91 \\
104 \\
128 \\
109\end{array}$ & \begin{tabular}{r|}
130 \\
104 \\
101 \\
142 \\
104 \\
99 \\
114 \\
91 \\
103 \\
122 \\
111
\end{tabular} & $\begin{array}{r}-6 \cdot 5 \\
+12 \cdot 7 \\
+35 \cdot 3 \\
+19 \cdot 1 \\
+47 \cdot 3 \\
+33 \cdot 6 \\
-29 \cdot 3\end{array}$ & $\begin{array}{r}-12.4 \\
-1.1 \\
+16.9 \\
+10.4 \\
-21.3 \\
-10.8 \\
+4.9\end{array}$ & $\begin{array}{r}+16.7 \\
0.0 \\
+2.3 \\
+6.9 \\
-4.8 \\
+15.0 \\
+14.2\end{array}$ & 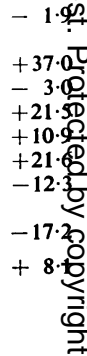 \\
\hline
\end{tabular}


Inhibition of histamine-stimulated gastric secretion by acid in the duodenum in man
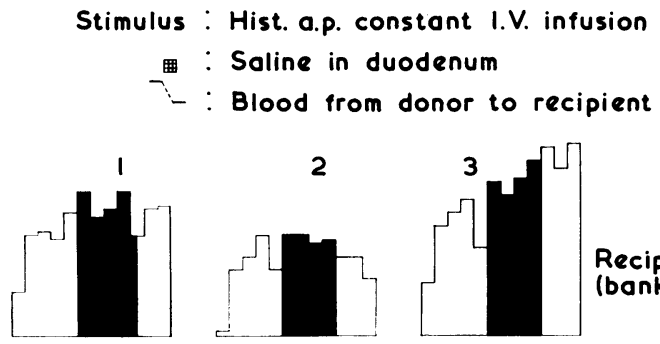

Recipients (bank blood)

FIG. 4. Rapid intravenous infusion of 1 pint of bank blood (experiments 1-3), fresh blood (4-6), 0.9\% saline with heparin (7-9), and plasma with heparin (10-12) did not inhibit histamine-stimulated gastric secretion.

FIG. 5. The stimulus was a histamine infusion.

In subjects 1, 2, and 3, who had complete vagotomy, gastric secretion decreased, but only slightly, when acid was put into the duodenum.

FIG. 5 .
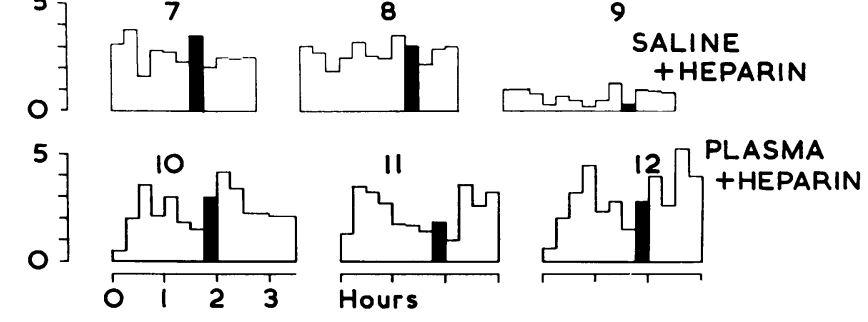

FIG. 4.

8

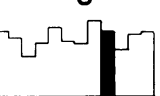

\section{SALINE}

+ HEPARIN

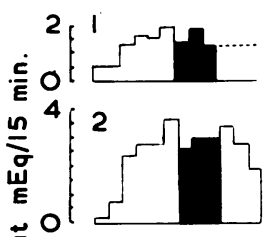

Insulin test

Inhibitory test
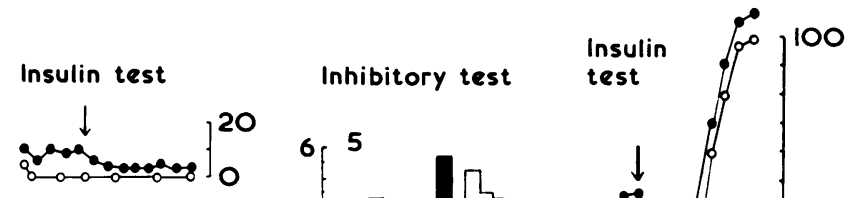<smiles>C1CCCCC1</smiles>
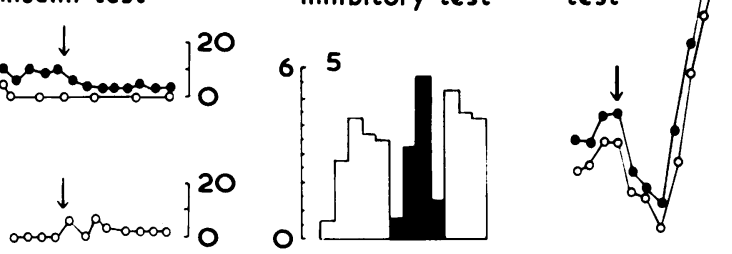

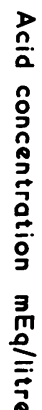
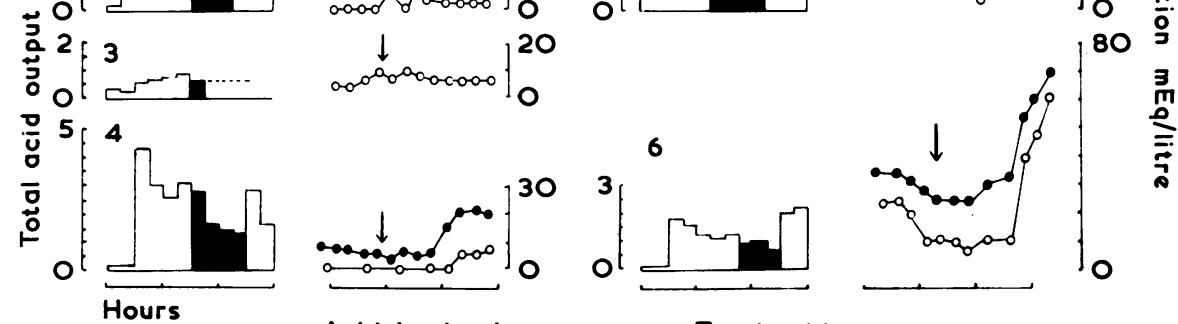

Acid in duodenum

Total acid $\cdots$.

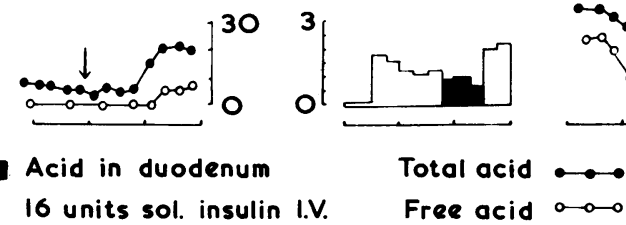




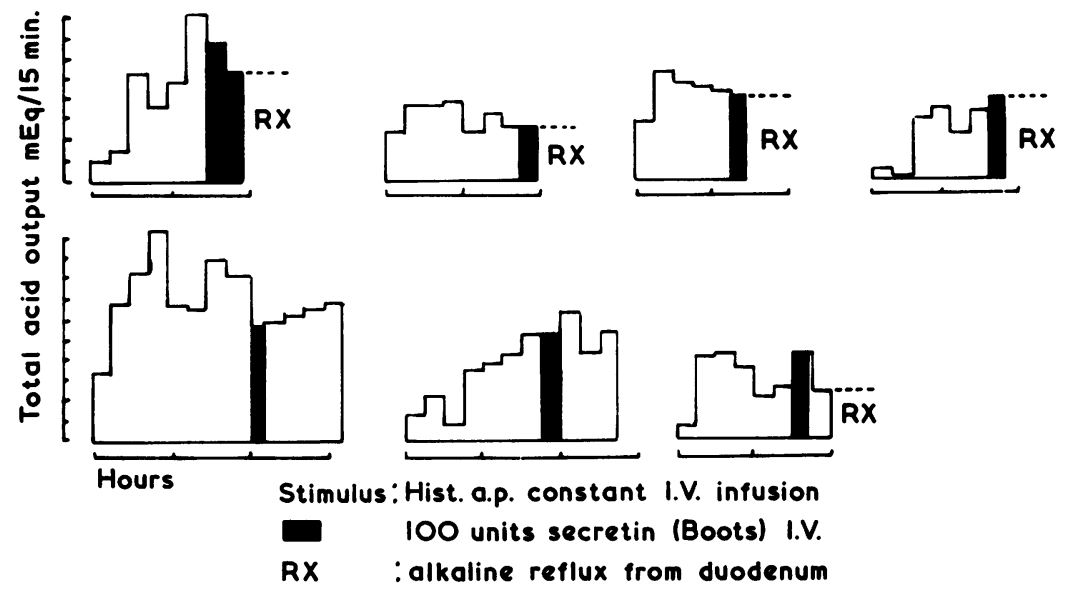

FIG. 6. The stimulus was a histamine infusion. Slow injection of secretin did not lead to significant inhibition.

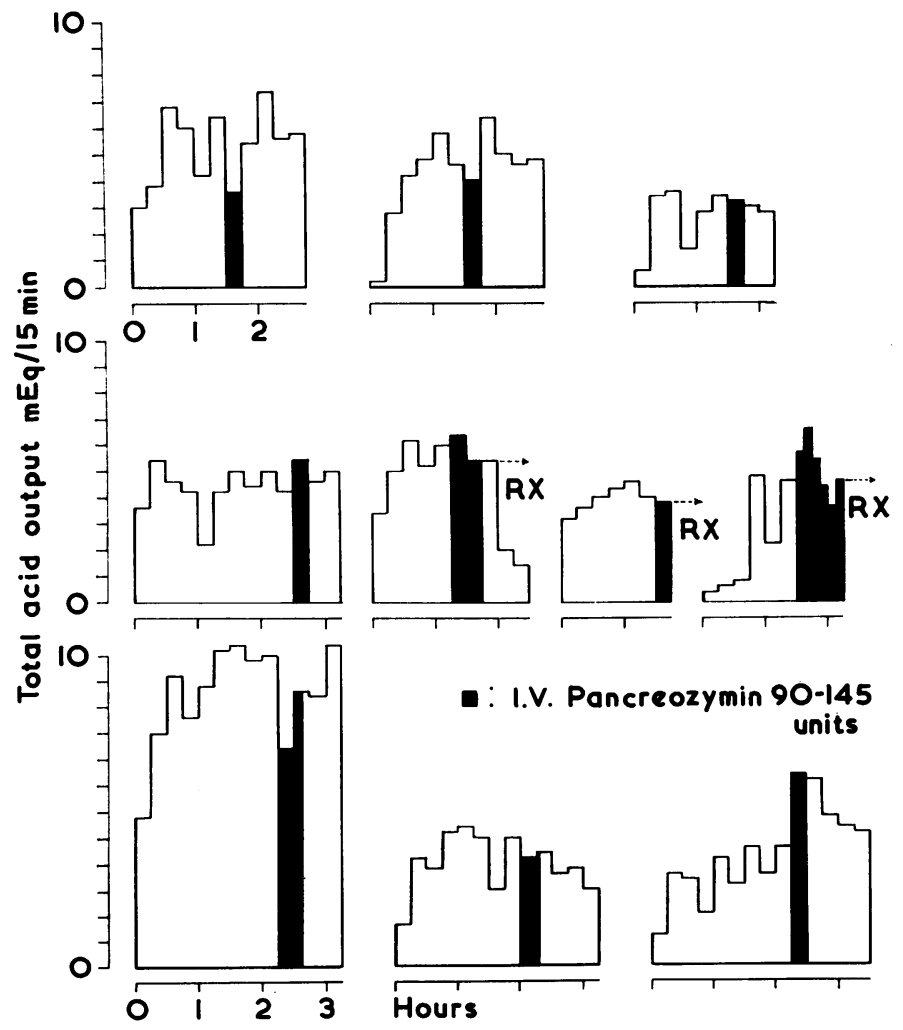

FIG. 7. Stimulus: histamine infusion. $R X=$ copious reflux of alkaline duodenal content.

PANCREOZYMIN In five tests, the acid output increased during intravenous administration of pancreozymin, and in five it decreased (Table V, Fig. 7). Over the 10 tests there was a mean increase of $6.1 \%$. These changes in acid secretion are not significant $(P>0.9)$. In the 15 -minute period after administration of pancreozymin, a mean increase in secretion of $17 \%$ was noted. Thus there was no delayed inhibition. No significant effect on acid concentration was seen nor was there any appreciable change in the concentration of the electrolytes or of pepsin, an increase of $18 \%$ noted in sodium concentration being attributable to reflux of the duodenal content. 
TABLE VI

EFFECT OF CHOLECYSTOKININ (CECEKIN) ON HISTAMINE-STIMULATED GASTRIC SECRETION

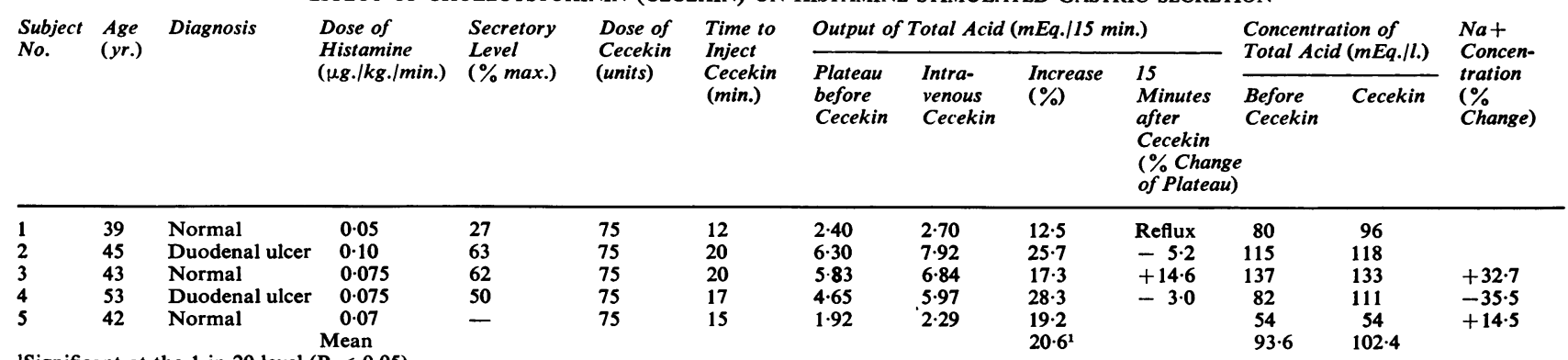

'Significant at the 1 in 20 level $(P<0.05)$

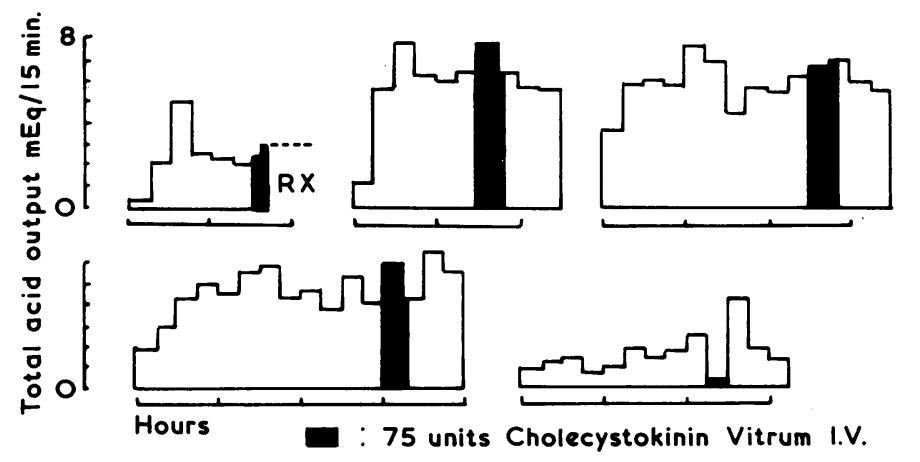

FIG. 8. Stimulus: histamine infusion.

$R X=$ copious reflux of alkaline duodenal content.

CHOLECYSTOKININ (Cecekin) No inhibition of gastric secretion was observed in any of the five tests (Table VI, Fig. 8): acid concentration increased slightly and no effect was noted on the concentration of pepsin or electrolytes. A mean increase in acid output of $20.6 \%$ occurred over the five tests, a change which is probably significant $(P<0.05)$. The graph shows an apparent decrease in secretion in test 5. A huge increase in the subject's gastric secretion took place in the ensuing 15-minute period, when a sudden gush of juice followed alteration in his position. The 'inhibition' had been due to a fault in aspiration. The mean of these two readings has therefore been taken as the acid output during the administration of Cecekin.

\section{DISCUSSION}

In any study on the inhibition of gastric acid secretion, endogenous acid must be prevented from passing through the pylorus into the duodenum during the control period, as Wormsley and Grossman (1964) have emphasized, for it may then produce an inhibition that will mask the inhibitory effect of the substance or procedure being tested. In the inhibitory test used in this study, little or no endogenous gastric acid entered the proximal duodenum, whose contents were being aspirated continuously via the duodenal tube and nearly always consisted of clear, golden, bilious fiuid of $p \mathbf{H}$ between 7 and 8 . Occasionally, the aspirate from the duodenal tube during the control period was of an opaque light-yellow colour, with a lower $p H$, between 6 and 2 . In these cases the usual explanation was that the more proximal suction holes were in the pyloric antrum, leading to aspiration of some gastric juice: the remedy lay in re-siting of the duodenal tube, and, if necessary, of the gastric tube too. Also, control tests (unpublished), in this laboratory, of the efficiency of gastric aspiration, in which a known weight of P.E.G. was dripped at a constant rate into the stomach via a second intragastric tube showed $80-100 \%$ recovery when the stomach was secreting at near-maximal rate. Thus it is unlikely that more than minimal volumes of acid reached the duodenum during the control period, and hence the duodenal mechanisms inhibiting gastric secretion would not have been activated at this time. The most cogent evidence in favour of this assertion is provided by the $50 \%$ inhibition of gastric secretion produced when acid was introduced into the duodenum. Unwanted 
movement of fluid in the other direction, from duodenum to stomach, was detected by P.E.G. estimations as described in the previous paper, and led to the test being discarded.

CROSS-TRANSFUSION TESTS The striking feature of the inhibition in the cross-transfusion tests was its similarity to that elicited by acid in the duodenum: the onset was rapid, the effect decayed soon after the stimulus was stopped, and the degree of inhibition was similar, $52 \%$ compared to $57 \%$ in the inhibitory test.

Although the results of cross-transfusion tests have to be interpreted warily, the technique has yielded useful information in the past. This method was used by Sandblom in 1933 to show the presence of a humoral substance causing contraction of the gall bladder, and Sircus (1964) has recently used the dog as the recipient to show that the blood of a patient with the Zollinger-Ellison syndrome had the property of stimulating gastric secretion. In the present study, the blood was infused rapidly in 15 minutes or so: it might be thought that this sudden increase in circulating blood volume might per se alter gastric secretion. The cross-circulation studies of DuVal and Price (1960 and 1961) showed that changes in gastric secretion might be attributable to alterations in blood volume and not to any specific substances in the transfused blood. However, we monitored the recipient's pulse rate carefully and noted no significant change when the blood was infused: no elevation of jugular venous pressure or other sign of circulatory strain was detected. Moreover, had the inhibition in these four tests been due to changes in blood volume, similar inhibition would have been expected to appear in the nine control experiments in which fresh blood, plasma, or saline were rapidly transfused. No such inhibition was seen.

Although Thompson and Lerner (1963) have shown that heparin can inhibit histamine-stimulated gastric secretion in man, the dose they employed was 10 times that used by us and it was administered by a single rapid intravenous injection whereas in the tests we report it was infused in the course of 15 minutes. The nine control studies using 2,250 units of heparin in fresh blood, in plasma, or in saline established that the heparin did not cause inhibition under the conditions of our experiment (Table II, Fig. 4).

SURGICAL VAGOTOMY This phase of the investigation proved disappointing because, for a variety of technical reasons, only six valid tests were obtained out of a total of 18 attempted; and of these six, three later proved to have been performed on subjects with positive insulin tests. Inhibition of about $18 \%$ seemed to take place in the three remaining tests on subjects whose insulin test had been negative. On the basis of these three it would be attractive to suggest that an inhibitory hormone had been responsible. However, in the absence of control studies on the same subjects, using histamine infusion alone without acid in the duodenum, it cannot be denied that this relatively small decrease in secretion might have occurred by chance. Even if the inhibition were genuine, it could conceivably have been brought about, not by a humoral substance but by local nervous reflexes in the wall of the stomach and duodenum or even by impulses travelling in sympathetic nerve fibres. Finally, because of our dependence on the result of the postoperative insulin test in nos. 2 and 3 (Fig. 5), some doubt must remain about the completeness of the vagotomy in these cases also. Allowing for these inadequacies, the results are consistent with the evidence for a humoral mechanism provided by the cross-transfusion tests.

EFFECT OF GASTROINTESTINAL HORMONAL SUBSTANCES It has been mentioned earlier that the preparations used were not pure, and indeed each of them doubtless possessed in some measure the properties of causing contraction of the gall bladder, and secretion of water and bicarbonate and of enzymes by the pancreas, associated with the names cholecystokinin, secretin, and pancreozymin. But the employment of these extracts seemed appropriate because the entry of acid gastric contents into the duodenum leads to a combination of the above activities on the part of the gall-bladder and pancreas.

SECRETIN (BOOTS) Over the seven tests, no evidence emerged to suggest that secretin was the factor responsible for the inhibition produced by acid in the duodenum. It could be suggested that an occult inhibition might have been unmasked had the histamine stimulus been weaker, or the dose of secretin larger or given in a shorter period of time. However, Lawrie, Smith, and Forrest (1964) have shown that a dose of about $0.67 \mu \mathrm{g} . / \mathrm{kg}$. $/ \mathrm{min}$. is required to elicit maximal levels of secretion: compared to this our doses were small and elicited rates of secretion $33,47,50$, and $83 \%$ of maximum, in the four tests in which the maximal secretory rates were also known. Moreover, we have shown previously that in normal subjects acid in the duodenum inhibits the gastric secretion elicited by intravenous infusion of histamine acid phosphate $0.2 \mu \mathrm{g} . / \mathrm{kg} . / \mathrm{min}$., a higher dose than was used in any of these tests. Larger doses of secretin given in one minute or so might have produced inhibition, 
but such massive stimulation would almost certainly have greatly exceeded any physiological stimulus. The failure of secretin in our study to inhibit histamine-stimulated gastric secretion is in accord with previous work in the dog (Gillespie and Grossman, 1964; Greenlee, Longhi, Guerrero, Nelsen, El-Bedri, and Dragstedt, 1957) although, in man, gastric secretion elicited by broth was inhibited by secretin (Kamionkowski et al., 1964). In a recent paper, however, Wormsley and Grossman (1964) showed that secretin inhibited histamine-stimulated gastric secretion from the vagally innervated main stomach of the dog, but did not inhibit the secretion from a Heidenhain pouch: yet acid in the duodenum could inhibit Heidenhain pouch secretion, whence these workers inferred that 'release of secretin was not the sole inhibitory mechanism elicited by endogenous acid in the duodenum'. Our findings are in agreement with this conclusion. These authors succeeded in showing that secretin inhibited histamine-stimulated gastric secretion from the main innervated stomach, while we failed to do so. This discrepancy may be due to the fact that they were using a different commercial extract or that they gave 75 units secretin rapidly in a single injection, whereas our speediest injection took six minutes. A remarkable feature was that inhibition of $28 \%$ was still apparent in their dogs at maximal rate of secretion.

PANCREOZYMIN (BOOTS) This preparation seemed to cause inhibition in five tests, which was counterbalanced by an equivalent augmentation in the other five tests, the net effect being a small increase of $6.1 \%$ in acid output. The doses of pancreozymin were large, and given slowly over 12 to 30 minutes because rapid injection led to epigastric pain and nausea on four occasions (these did not always coincide with inhibition.) In view of the conflicting nature of these results after giving pancreozymin, it seems unlikely that the inhibition of gastric secretion evoked by acid in the duodenum could be attributable solely to release of this hormone.

CHOLECYSTOKININ (CECEKIN) There was an increase in secretion of gastric acid in five tests, the mean being $20.6 \%$. This stimulant action has already been recorded by Preshaw and Grossman (1965) in a study on dogs. Our findings contrast with the demonstration by Gillespie and Grossman (1964) that a single rapid injection of Cecekin inhibited the response to low doses of histamine in dogs with Heidenhain pouches.

Again, one would concede that even lower doses of histamine or higher doses of cholecystokinin might have allowed us to demonstrate inhibition.
However, this possibility is unlikely, since higher doses of cholecystokinin would probably have produced nausea and pain, and in one test the secretory level was only $27 \%$ of maximal, which surely should be low enough, especially since in that test the injection of cholecystokinin was most rapid.

Our main object in doing this group of tests was to see whether these extracts caused inhibition of gastric secretion. When gastric secretion was unaltered or increased one could conclude that the hormonal preparation did not cause inhibition. Difficulties in interpretation arose only when a decrease in secretion took place, because one had to consider the part played by alkaline reflux from the duodenum, which by its neutralizing effect on gastric acid could give the appearances of inhibition. The occurrence of reflux has been detected using these criteria. (1) Was there bile-staining of the gastric aspirate? (2) Did the concentration of the gastric juice decrease and (3) did the sodium concentration increase? Over the 22 tests, reflux occurred in six and could not be correlated either with inhibition or with stimulation of gastric secretion.

We have shown previously that acidifying the duodenum of normal men to a $p \mathrm{H}$ of under 2.5 leads to inhibition of gastric secretion in response to intravenous infusion of histamine acid phosphate, $0.2 \mu \mathrm{g} . / \mathrm{kg}$. $/ \mathrm{min}$. In this study, despite using smaller doses of histamine, generally in the range 0.05 to $0.1 \mu \mathrm{g} . / \mathrm{kg} . / \mathrm{min}$., to stimulate gastric secretion, we have been unable to elicit a similar inhibition by the intravenous injection of gastrointestinal extracts containing secretin, pancreozymin, and cholecystokinin. It is true that mild inhibition did seem to take place in a few tests, but the net effect was nil, whereas acid in the second part of the duodenum almost always led to decisive inhibition. This suggests that such inhibition is not mediated, solely at any rate, by these hormones: we have not, however, investigated their effect on gastric secretion when they all act in concert.

\section{SUMMARY}

Three distinct lines of investigation have been used in an attempt to discover how acid in the duodenum inhibits histamine-stimulated gastric secretion in man. In all tests, histamine acid phosphate was given in low dosage at a constant rate intravenously.

The investigation suffers from some typical defects of a study on man. The numbers are small, and it has not been possible to perform repeated tests on the same individual. However, the following conclusions can be drawn.

Gastric secretion was inhibited in the cross- 
transfusion tests but not in control cross-transfusions. This inhibition is attributed to a hormonal substance.

Injection of extracts of duodenal mucosa containing secretin, cholecystokinin, and pancreozymin did not reproduce inhibition characteristic of acid in the duodenum.

The inconclusive studies on subjects with surgical vagotomy are compatible with the hypothesis that a hormone is involved in the inhibition.

It is suggested that the inhibition of histaminestimulated gastric secretion by acid in the duodenum in man has a humoral component, as yet undefined.

Most of this work was done at Leeds General Infirmary. We thank Professor J. C. Goligher for his constant encouragement during this study. We are greatly indebted to Mr. A. A. MacKelvie of Stirling Royal Infirmary for enthusiastic support and the privilege of testing his patients. We thank too Mr. Kirton, of the Department of Surgery, at Leeds for his excellent technical services and the staff of the Radiology Department for their help with screening. Not least, we are grateful to the volunteers for their cheery fortitude.

\section{REFERENCES}

Andersson, S. (1960a). Inhibitory effects of hydrochloric acid in antrum and duodenum on gastric secretory responses to test meal in Pavlov and Heidenhain pouch dogs. Acta physiol. scand., 49, 231-241.

(1960b). Inhibitory effects of hydrochloric acid in antrum and duodenum on histamine-stimulated gastric secretion in Pavlov and Heidenhain pouch dogs. Ibid., 50, 186-196.

Code, C. F., and Watkinson, G. (1955). Importance of vagal innervation in the regulatory effect of acid in the duodenum on gastric secretion of acid. J. Physiol. (Lond.), 130, 233-252.
DuVal, M. K. Jr., and Price, W. E. (1960). The mechanism of antral regulation of gastric secretion: continuous cross-circulation. Ann. Surg., 152, 410-415.

,- (1961). Mechanism of antral regulation of gastric secretion: discontinuous cross-circulation. Ibid., 153, 581-584.

Gillespie, I. E., and Grossman, M. I. (1964). Inhibitory effect of secretin and cholecystokinin on Heidenhain pouch responses to gastrin extract and histamine. Gut, 5, 342-345.

Greenlee, H. B., Longhi E., H., Guerrero, J. D., Nelsen, T. S. El-Bedri, A. L., and Dragstedt, L. R. (1957). Inhibitory effect of pancreatic secretin on gastric secretion. Amer. J. Physiol., 190, 396-402.

Hollander, F. (1948). Laboratory procedures in the study of vagotomy (with particular reference to the insulin test). Gastroenterology, 11, 419-425.

Hunt, J. N. (1948). A method for estimating peptic activity in gastric contents. Biochem. J., 42, 104-109.

Johnston. D., and Duthie, H. L. (1964). Effect of acid in the duodenum on histamine-stimulated gastric secretion in man. Gut, 5, 573-580.

Kamionkowski, M., Grossman, S., and Fleschler, B. (1964). The inhibitory effect of secretin on broth-stimulated gastric secretion in human subjects. Gut, 5, 237-240.

Lawrie, J. H., Smith, G. M. R., and Forrest, A. P. M. (1964). The histamine-infusion test. Lancet, 2, 270-273.

Mollison, P. L. (1961). Blood Transfusion in Clinical Medicine, 3rd edition, p. 505. Blackwell, Oxford.

Pappas, G., and Code, C. F. (1963). The role of the antrum and the vagus nerves in the inhibition of gastric secretion by duodenal acidification. Gastroenterology, 44, 861. (Abstract).

Preshaw, R. M., and Grossman, M. I. (1965). Stimulation of pancreatic secretion by extracts of the pyloric gland area of the stomach. Ibid., 48, 36-44.

Sandblom P. (1933). The function of the human gallbladder studied in connection with blood transfusions and after stomach operations. Acta radiol. (Stockh.), 14, 249-258.

Sircus, W. (1958). Studies on the mechanisms in the duodenum inhibiting gastric secretion. Quart. J. exp. Physiol., 43, 114-133.

- (1964). Evidence for a gastric secretagogue in the circulation and gastric juice of patients with the Zollinger-Ellison syndrome. Lancet, 2, 671-672.

Thompson, J. C., and Lerner, H. J. (1963). Inhibition of gastric secretion by heparin. Gastroenterology, 44, 856. (Abstract).

Wormsley, K. G., and Grossman, M. I. (1964). Inhibition of gastric acid secretion by secretin and by endogenous acid in the duodenum. Ibid., 47, 72-81. 